\title{
KONSERVATISME AKUNTANSI DI INDONESIA
}

\author{
Hans Hananto Andreas \\ Fakultas Ekonomika dan Bisnis, Universitas Kristen Satya Wacana Salatiga \\ hananto.andreas@staff.uksw.edu
}

Albert Ardeni

Fakultas Ekonomika dan Bisnis, Universitas Kristen Satya Wacana Salatiga

232011042@student.uksw.edu

Paskah Ika Nugroho

Fakultas Ekonomika dan Bisnis, Universitas Kristen Satya Wacana Salatiga

paskah@staff.uksw.edu

\begin{abstract}
This study aims to provide empirical evidence on the influence of company growth, profitability, and investment opportunity set (IOS) on the application of the accounting conservatism principles. We measure accounting conservatism using total accrual (earnings before extraordinary items + depreciation - cash flow from operation). We purposively select our sample of 114 manufacturing firms listed in the Indonesian Stock Exchange (IDX) in the years 2012-2013. After running the tests of classical assumptions, our multiple regression analysis partially shows that company growth, profitability, and investment opportunity set positively affect accounting conservatism.
\end{abstract}

Keywords: accounting conservatism, company growth, profitability, investment opportunity set.

\begin{abstract}
ABSTRAK
Dalam penyajian laporan keuangan yang berkualitas, perusahaan dihadapkan oleh pertimbangan yang salah satunya adalah penerapan konservatisme akuntansi. Penelitian ini bertujuan untuk memberikan bukti empiris pengaruh company growth, profitability, dan investment opportunity set (IOS) terhadap penerapan prinsip konservatisme akuntansi. Konservatisme akuntansi dalam penelitian ini diukur menggunakan perhitungan total akrual. Total akrual adalah selisih antara laba sebelum extraordinary item ditambah dengan depresiasi dikurangi dengan arus kas operasi untuk mengetahui apakah perusahaan menggunakan konservatisme akuntansi tinggi atau rendah di dalam perusahaan. Sampel yang digunakan sebanyak 114 perusahaan manufaktur yang terdaftar di Bursa Efek Indonesia (BEI) di tahun 2012 dan 2013. Metoda pemilihan sampel yang digunakan yaitu purposive sampling. Alat analisis yang digunakan untuk pengujian adalah regresi linier berganda yang sebelumnya harus lolos uji asumsi klasik. Hasil pengujian secara parsial menunjukkan company growth, profitability dan investment opportunity set berpengaruh positif signifikan terhadap konservatisme akuntansi.
\end{abstract}


Kata Kunci: accounting conservatism, company growth, profitability, investment opportunity set.

\section{PENDAHULUAN}

Laporan keuangan yang disiapkan oleh perusahaan menunjukkan kinerja manajemen perusahaan dalam mengelola sumber daya perusahaan. Informasi dalam laporan keuangan tersebut digunakan oleh pihak internal yaitu manajer dalam mengambil keputusan maupun pihak eksternal yaitu investor, karyawan, kreditur, pemerintah dan masyarakat. Laporan keuangan perusahaan yang disusun berdasarkan prinsip akuntansi yang berterima umum memberikan fleksibilitas bagi manajemen dalam menentukan metoda dan estimasi akuntansi yang digunakan. Fleksibilitas tersebut akan mempengaruhi perilaku manajer dalam melakukan pencatatan akuntansi dan pelaporan teransaksi perusahaan (Wardhani 2008). Dengan adanya fleksibilitas, manajer dapat melakukan pelaporan keuangan yang optimis maupun konservatif. Pelaporan keuangan yang optimis serta cenderung melebih-lebihkan terkadang menyesatkan dan merugikan pengguna laporan keuangan (Ardina \& Januarti 2012). Perusahaan teridentifikasi melakukan kecurangan dengan cara melebihkan nilai aset yang ada, mencatat aset fiktif, atau mengkapitalisasi unsurunsur yang seharusnya dibebankan. Hal tersebut diduga dilakukan oleh manajemen dengan maksud menghindari kerugian sebelum pajak, untuk mematuhi peraturanperaturan agar saham perusahaan dapat diperjualbelikan di bursa saham nasional, serta meningkatkan harga saham (Ardina \& Januarti 2012). Dalam penyajian laporan keuangan yang berkualitas, penyaji juga dihadapkan oleh pertimbangan konservatisme yang merupakan prinsip kehati-hatian. Konservatisme merupakan reaksi yang berhati-hati atas ketidakpastian yang ada agar ketidakpastian dan risiko yang berkaitan dalam situasi bisnis dapat dipertimbangkan dengan cukup memadai (Almilia 2004). Konservatisme jika diterapkan dapat mengurangi kemungkinan manajer melakukan manipulasi laporan keuangan (LaFond \& Watts 2006). Penerapan konservatisme dapat menyebabkan laba yang berfluktuatif, yang akan mengurangi daya prediksi laba untuk memprediksi arus kas di masa depan (Sari \& Adhariani 2009). Zulaikha (2012) menyatakan bahwa kritikan terhadap penerapan prinsip konservatisme yaitu, konservatisme dianggap sebagai kendala yang akan mempengaruhi laporan keuangan. Apabila metoda yang digunakan dalam penyusunan laporan keuangan berdasarkan prinsip akuntansi yang sangat konservatif, maka hasilnya cenderung bias dan tidak mencerminkan kenyataan. Di sisi lain, konservatisme akuntansi bermanfaat untuk menghindari perilaku oportunistik manajer (Watts 2003). LaFond dan Watts (2006) juga menjelaskan bahwa laporan keuangan yang konservatif dapat mencegah adanya information asymmetry dengan cara membatasi manajemen dalam melakukan manipulasi laporan keuangan. 
Dari beberapa penelitian yang telah dilakukan sebelumnya terkait faktorfaktor yang mempengaruhi penerapan prinsip konservatisme akuntansi, terdapat perbedaan hasil penelitian. Saputri (2013) memberi temuan bahwa company growth dengan konservatisme akuntansi tidak berpengaruh terhadap konservatisme akuntansi. Hasil tersebut berbanding terbalik dengan penelitian Ahmed dan Duellman (2007) yang menyatakan company growth diukur dengan pertumbuhan penjualan akan mempengaruhi konservatisme melalui ukuran akrual dan nilai pasar. Pengujian Astuti (2015); Zulaikha (2012), serta Martani dan Dini (2010) menemukan hasil pertumbuhan penjualan berpengaruh negatif terhadap konservatisme akuntansi secara akrual, Profitability dan konservatisme akuntansi berpengaruh positif terhadap konservatisme akuntansi (Saputri 2013; Wardhani 2008; dan Zulaikha 2012). Hasil tersebut tidak konsisten dengan penelitian Dwitayanti dan Fahlevi (2015). Pengujian konservatisme yang lain adalah Investment Opportunity Set (IOS) yang ditemukan berpengaruh positif terhadap penerapan prinsip konservatisme akuntansi (Dwitayanti \& Fahlevi 2015; Saputri 2013). Hasil penelitian sebelumnya mengenai faktor-faktor yang mempengaruhi konservatisme akuntansi dengan menggunakan data laporan keuangan pada perusahaan manufaktur yang terdaftar di Bursa Efek Indonesia dengan periode yang berbeda menunjukkan hasil yang inkonklusif, hal ini memotivasi dilakukan penelitian kembali dengan objek perusahaan manufaktur pada tahun 2012-2013.

Penelitian ini merupakan replikasi dari penelitian yang dilakukan oleh Saputri (2013). Penelitian ini memilih periode objek penelitian tahun 2012-2013 untuk mengetahui apakah pada periode ini hasilnya akan konsisten atau berbeda dengan penelitian sebelumnya yang menggunakan periode objek penelitian tahun 2009-2010 yang masih terkena dampak krisis ekonomi global. Pertimbangan pemilihan perusahaan manufaktur sebagai objek karena sebagian besar perusahaan di Indonesia merupakan perusahaan yang bergerak di bidang manufaktur. Ini juga bertujuan untuk menghindari bias karena perbedaan industri dan sektor manufaktur mempunyai akun relatif besar yang tentunya mempunyai ekuitas yang besar pula (Yenti \& Syofyan 2013). Berbeda dengan penelitian sebelumnya yang dilakukan Saputri ( 2013) dalam penelitian ini menggunakan perhitungan akrual untuk menghitung nilai konservatisme dan tidak menggunakan cash flow sebagai variabel bebas.

Persoalan penelitian yang dikaji dalam penelitian ini adalah: pertama, apakah ada pengaruh company growth terhadap konservatisme? kedua, apakah ada pengaruh profitability terhadap konservatisme? serta apakah ada pengaruh investment opportunity set terhadap konservatisme? Penelitian ini diharapkan berkontribusi dalam pengembangan teori akuntansi, khususnya terkait konsep konservatisme akuntansi. Penelitian ini diharapkan dapat menjadi masukan bagi peneliti lain yang melakukan penelitian sejenis. Penelitian ini diharapkan mampu menjadikan pertimbangan bagi para investor dan kreditur dalam melakukan investasi atau memberikan pinjaman dalam menganalisis laba. Penelitian ini diharapkan mampu 
membantu manajer dalam menerapkan konservatisme, yang kemungkinan dapat mengurangi masalah keagenan.

\section{KAJIAN PUSTAKA DAN PERUMUSAN HIPOTESIS}

\section{Teori Keagenan}

Teori agensi merupakan teori yang digunakan perusahaan dalam mendasari praktik bisnisnya. Oktomegah (2012) menyatakan bahwa teori keagenan disebut juga sebagai teori kontraktual yang memandang suatu perusahaan sebagai suatu perikatan kontrak antara anggota-anggota perusahaan. Teori keagenan ini menjelaskan bahwa terdapat perbedaan kepentingan antara pemilik perusahaan dengan manajer. Pemilik perusahaan atau investor menginginkan laba seolah tampak tidak besar untuk menghindari pajak yang terlalu besar. Sedangkan manajer perusahaan menginginkan agar laba terlihat besar sehingga kinerja manajer sendiri terlihat baik. Tentu hal ini menjadi masalah karena kedua belah pihak memiliki kepentingan masing-masing. Untuk mencegah kejadian seperti ini perusahaan perlu melakukan agency cost. Agency cost sendiri digunakan untuk mengurangi kerugian akibat tingkah laku dari manager tersebut. Watts (2003) menyatakan bahwa konservatisme akuntansi muncul dari insentif yang berkaitan dengan biaya kontrak, litigasi, pajak, dan politik yang bermanfaat bagi perusahaan untuk mengurangi biaya keagenan dan mengurangi pembayaran yang berlebihan kepada pihak-pihak seperti manajer, pemegang saham, pengadilan dan pemerintah.

LaFond dan Watts (2006) berpendapat bahwa laporan keuangan yang mengaplikasikan prinsip konservatisme dapat mengurangi kemungkinan manajer melakukan manipulasi laporan keuangan serta biaya agensi yang muncul akibat dari asimetri informasi. Asimetri informasi merupakan kondisi bahwa pihak manajemen memiliki infomasi lebih banyak dibandingkan dengan pihak investor. Salah satu penyebab terjadinya manipulasi laporan keuangan adalah terjadinya asimetri informasi dalam teori keagenan. Perilaku manipulasi yang paling sering terjadi dalam teori keagenan adalah pencatatan laba yang tinggi. Latar belakang yang menyebabkan perilaku ini adalah adanya insentif manajemen berupa bonus yang diukur dari kerja manajemen dalam mencapai laba, serta menjadi perhatian penting bagi calon investor dalam melakukan pertimbangan pengambilan keputusan. Faktorfaktor tersebut menyebabkan manajer bertindak untuk memilih metoda akuntansi yang mampu memanipulasi laporan keuangan. Dengan menerapkan perilaku konservatisme dapat mencegah manajer melakukan manipulasi laporan keuangan.

\section{Konservatisme Akuntansi}

Konservatisme merupakan prinsip kehati-hatian dalam pelaporan keuangan dimana perusahaan tidak terburu-buru dalam mengakui dan mengukur aset dan laba serta segera mengakui kerugian dan hutang yang mempunyai kemungkinan yang 
terjadi. Penerapan prinsip ini mengakibatkan pilihan metoda akuntansi yang melaporkan laba atau aset yang lebih rendah serta melaporkan hutang lebih tinggi (Watts 2003).

Dalam konsep ini, beban diakui lebih cepat dan pendapatan diakui lebih lambat, sehingga net income terlihat rendah. Selanjutnya, konservatisme akan menyebabkan pelaporan keuangan yang pesimistik, hal tersebut akan mengurangi optimisme dari pengguna laporan (Ardina \& Januarti 2012). Tujuan dari penggunaan konsep konservatisme adalah untuk menetralisir optimisme para usahawan yang terlalu berlebihan dalam melaporkan hasil usahanya. Penerapan konsep konservatisme akan menghasilkan laba yang berfluktuatif, dimana laba yang berfluktuatif akan mengurangi daya prediksi laba untuk memprediksi aliran kas pada masa depan (Sari \& Adhariani 2009).

\section{Pengaruh Company Growth terhadap Konservatisme}

Pertumbuhan perusahaan (company growth) merupakan suatu harapan penting yang diinginkan oleh pihak internal perusahaan yaitu manajemen maupun eksternal perusahaan seperti investor dan kreditor. Pertumbuhan perusahaan dapat diukur dengan pertumbuhan penjualan, pertumbuhan laba, pertumbuhan nilai buku ekuitas, dan pertumbuhan aset. Dalam penelitian ini pertumbuhan perusahaan diukur pertumbuhan penjualan (sales growth) karena pertumbuhan penjualan akan mempengaruhi tingkat akrual pada perusahaan seperti persediaan, piutang dan lainnya. Pertumbuhan penjualan akan mempengaruhi konservatisme melalui ukuran akrual dan nilai pasar (Ahmed \& Duellman 2007). Pertumbuhan penjualan yang tinggi seringkali meningkatkan ekspektasi pasar terhadap arus kas di masa depan sehingga akan mempengaruhi konsevatisme. Pertumbuhan perusahaan di masa mendatang menandakan bahwa perusahaan telah mencapai tingkat keuntungan yang tinggi. Semakin tinggi pertumbuhan penjualan mengindikasikan bahwa perusahaan tersebut semakin konservatif. Hal ini didukung oleh hasil penelitian Ahmed dan Duellman (2007) yaitu pertumbuhan penjualan berpengaruh positif terhadap konservatisme. Dengan argumentasi dan hasil riset terdahulu, maka dirumuskan hipotesis pertama sebagai berikut.

H1: Company growth berpengaruh positif terhadap konservatisme.

\section{Pengaruh Profitability terhadap Konservatisme}

Tingkat profitabilitas yang tinggi pada perusahaan akan meningkatkan daya saing antar perusahaan. Perusahaan yang memperoleh tingkat keuntungan yang tinggi akan membuka lini atau cabang yang baru serta memperbesar investasi atau membuka investasi baru terkait dengan perusahaan induknya. Tingkat keuntungan yang tinggi menandakan pertumbuhan perusahaan pada masa mendatang. Lestari (2004) menyatakan bahwa profitabilitas menunjukkan kemampuan perusahaan untuk menghasilkan laba. Perusahaan dengan profitabilitas yang lebih tinggi akan memiliki kesempatan bersaing lebih baik dengan jenis perusahaan yang sama. Profitabilitas 
yang tinggi memberikan sinyal mengenai pertumbuhan perusahaan di masa yang akan datang. Profitabilitas yang tinggi akan membuat perusahaan memiliki laba ditahan yang banyak yang mengindikasikan adanya penerapan prinsip konservatisme akuntansi. Profitabilitas perusahaan digunakan sebagai variabel independen karena perusahaan yang memperoleh keuntungan lebih cenderung untuk menggunakan prinsip akuntansi konservatif (Wardhani 2008). Profitabilitas perusahaan dalam penelitian ini diukur dengan Return on Equiity (ROE). Jika ROE perusahaan tinggi, maka jumlah laba ditahan akan meningkat dan menyebabkan pula peningkatan konservatisme akuntansi (Saputri 2013). Penggunaan ROE untuk ukuran profitabilitas dalam penelitian ini dilandasi oleh alasan bahwa $R O E$ memberi gambaran tentang kemampuan perusahaan dalam memberikan kompensasi keuangan kepada pemegang saham melalui ekuitas perusahaan. Dengan mendasarkan pada argumentasi dan hasil riset terdahulu, maka dirumuskan hipotesis dua sebagai berikut.

H2: Profitability berpengaruh positif terhadap konservatisme.

\section{Pengaruh Investment Opportunity Set terhadap Konservatisme}

Dwitayanti dan Fahlevi (2015) berargumen bahwa IOS merupakan sekumpulan keputusan investasi dalam bentuk aset yang dimiliki dan pilihan investasi masa depan. Nilai IOS itu sendiri mempengaruhi nilai perusahaan. Dwitayanti dan Fahlevi (2015) menyatakan adanya hubungan antara Investment Opportunity Set (IOS) dan konservatisme akuntansi. Akuntansi secara tradisional tidak merespon perubahan nilai pertumbuhan dan aset tidak berwujud perusahaan. Akuisisi dan perubahan nilai akibat penurunan nilai dari aset biasanya tidak dicatat kecuali secara eksternal diperoleh dan dapat diverifikasi (seperti goodwill manajer dan akuisisi). Apabila terjadi penurunan nilai aset yang tidak dicatat, maka perusahaan tidak dapat mengakuinya. Hal ini mengarahkan perusahaan pada tingkat konservatisme yang rendah terutama ketika nilai perusahaan dipengaruhi oleh nilai pertumbuhan dan nilai aset tidak berwujud perusahaan. Secara singkat dapat disimpulkan bahwa IOS yang semakain besar akan rawan dengan adanya penurunan nilai aset terutama aset tidak berwujud yang tidak diakui. Hal ini menjadikan asosiasi yang negatif antara $I O S$ dengan konservatisme akuntansi. Hal ini sejalan dengan teori yang diungkapkan oleh Lafond dan Roychowdhury (2007). Dengan argumentasi dan hasil riset terdahulu, maka dirumuskan hipotesis tiga sebagai berikut.

H3: Investment opportunity set berpengaruh negatif terhadap konservatisme.

\section{METODA PENELITIAN}

\section{Jenis Data}

Penelitian ini merupakan penelitian kuantitatif. Data yang digunakan dalam penelitian ini adalah laporan keuangan tahunan perusahaan yang terdaftar di Bursa 
Efek Indonesia (BEI) pada tahun 2012-2013. Data-data tersebut diperoleh dari IDX data base (www.idx.co.id) dan Indonesian Capital Market Directory.

\section{Populasi dan Sampel Penelitian}

Populasi dalam penelitian ini adalah perusahaan manufaktur yang tercatat di BEI pada periode 2012 sampai dengan 2013. Pengambilan sampel dilakukan dengan metoda purposive sampling dengan kriteria-kriteria sebagai berikut: a) perusahaan yang menyajikan laporan keuangan dalam bentuk rupiah selama periode penelitian, b) perusahaan yang mempunyai laporan keuangan tahunan dan yang menerbitkan laporan keuangan tahunan secara lengkap dan jelas serta sudah diaudit dan perusahaan manufaktur yang memiliki kelengkapan data untuk penelitian ini.

\section{Definisi Operasional dan Pengukuran Variabel Penelitian}

\section{Variabel Dependen}

Variabel dependen dalam penelitian ini yaitu konservatisme akuntansi menggunakan perhitungan total akrual yang mengacu pada penelitian Givoly dan Hayn (2000).

KAit $=$ NIit - CFOit $\times(-1)$ 1

Keterangan:

KAit $=$ Tingkat konservatisme perusahaan i pada tahun $\mathrm{t}$

NIit = Laba sebelum extraordinary item ditambah dengan depresiasi perusahaan i pada tahun $\mathrm{t}$

CFOit $=$ Cash flow dari kegiatan operasi untuk perusahaan i pada tahun $\mathrm{t}$

- Jika nilai KAit >0, artinya perusahaan itu mempunyai tingkat konservatisme akuntansi yang tinggi

- Jika nilai KAit $<0$, artinya perusahaan itu mempunyai tingkat konservatisme akuntansi yang rendah

Perusahaan dikatakan memiliki tingkat konservatisme akuntansi yang tinggi jika nilai $\mathrm{KA}_{\mathrm{it}}$ di atas nol (positif). Hal ini dikarenakan laba yang tercantum di dalam laporan keuangan lebih besar daripada kas yang tersedia untuk kegiatan operasional. Sebaliknya perusahaan akan dikatakan memiliki tingkat konservatisme akuntansi yang rendah jika nilai $\mathrm{KA}_{\text {it }}$ di bawah nol (negatif). Hal ini dikarenakan laba yang tercantum di laporan keuangan lebih kecil daripada kas yang tersedia untuk kegiatan operasional.

\section{Variabel Independen}

\section{Company Growth}

Pertumbuhan perusahaan merupakan kemampuan perusahaan untuk meningkatkan size dengan adanya peningkatan aset, ekuitas, laba dan penjualan. Pertumbuhan merupakan elemen yang terjadi dalam siklus perusahaan. Ukuran pertumbuhan dalam perusahaan tergantung dari kegiatan perusahaan. Pengertian pertumbuhan dalam manajemen keuangan pada umumnya menunjukkan peningkatan ukuran skala perusahaan. Biasanya dalam mengukur pertumbuhan dilakukan dengan menghitung input atau outputnya, yaitu dengan menggunakan ukuran fisik 
perusahaan, seperti luas tanah, gedung, peralatan kantor dan aset tetap lainnya. Namun dalam mengukur pertumbuhan perusahaan yang menggunakan ukuran fisik perusahaan sulit untuk dibandingkan dengan perusahaan lain (Aristantia dan Putra 2015). Company growth dalam penelitian ini diukur dengan pertumbuhan penjualan (Sales Growth). Pertumbuhan penjualan akan mempengaruhi konservatisme melalui ukuran akrual dan nilai pasar (Ahmed dan Duellman 2007).

Pertumbuhan Penjualan $=\frac{\text { Total Penjualan } \mathrm{Neto}_{\mathrm{t}}-{\text { Total Penjualan } \mathrm{Neto}_{\mathrm{t}-1}}_{\text {Total Penjualan Neto }} \mathrm{t}-1}{\text {.................................. } 2}$

\section{Profitability}

Profitabilitas merupakan salah satu pengukuran bagi kinerja suatu perusahaan, profitabilitas suatu perusahaan menunjukkan kemampuan suatu perusahaan dalam menghasilkan laba selama periode tertentu pada tingkat penjualan, aset dan modal saham tertentu. Profitabilitas suatu perusahaan dapat dinilai melalui berbagai cara tergantung pada laba dan aset atau modal yang akan diperbandingkan satu dengan lainya. Return on equity atau profitabilitas adalah suatu pengukuran dari penghasilan atau income yang tersedia bagi pemilik perusahaan atas modal yang telah diinvestasikan di dalam perusahaan (Gitman 2003). Profitability suatu perusahaan dalam penelitian ini diukur dengan Return On Equity (ROE). ROE Merupakan gambaran perbandingan antara laba bersih setelah pajak dengan total ekuitas perusahaan.

$\mathrm{ROE}=\frac{\text { Laba Bersih Setelah Pajak }}{\text { Total Ekuitas }}$

\section{Investment Opportunity Set}

Pilihan investasi merupakan suatu kesempatan untuk berkembang, namun seringkali perusahaan tidak selalu dapat melaksanakan semua kesempatan investasi di masa mendatang. Bagi perusahaan yang tidak dapat menggunakan kesempatan investasi tersebut akan mengalami suatu pengeluaran yang lebih tinggi dibandingkan dengan nilai kesempatan yang hilang. Nilai kesempatan investasi merupakan nilai sekarang dari pilihan-pilihan perusahaan untuk membuat investasi di masa mendatang. Secara umum dapat dikatakan bahwa IOS menggambarkan tentang luasnya kesempatan atau peluang investasi bagi suatu perusahaan, namun sangat tergantung pada pilihan expenditure perusahaan untuk kepentingan di masa yang akan dating (Aristantia dan Putra 2015).

IOS $=\frac{\text { Nilai Buku Aset Tetap }}{t-\text { Nilai Buku Aset Tetap }}$ Tot-1 $_{\text {Aset }}$

\section{Teknik dan Analisis}

Metoda analisis yang digunakan dalam penelitian ini adalah model regresi linear berganda yang sebelumnya harus lolos uji asumsi klasik. Uji asumsi klasik 
yang digunakan meliputi uji normalitas, autokorelasi, multikolinearitas, serta heteroskedastisitas.

Rumus regresi linier berganda adalah sebagai berikut:

$Y=a+b 1 X 1+b 2 X 2+b 3 X 3+e$ 5

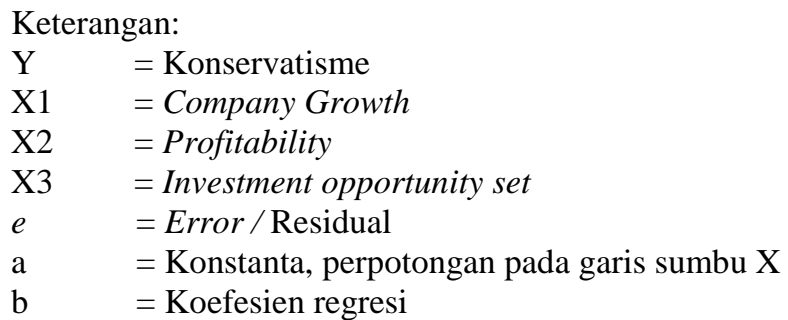

\section{ANALISIS DAN PEMBAHASAN}

\section{Hasil Pengumpulan Data}

Penelitian ini bertujuan untuk menguji pengaruh faktor-faktor yang mempengaruhi konservatisme akuntansi pada perusahaan manufaktur yang terdaftar di Bursa Efek Indonesia (BEI) periode tahun 2012-2013. Berdasarkan kriteria yang telah ditentukan sebelumnya, diperoleh sampel penelitian sebesar 228 perusahaan (Tabel 1).

Tabel 1

Hasil Pengambilan Sampel

\begin{tabular}{lc}
\hline \multicolumn{1}{c}{ Kriteria Sampel } & Jumlah \\
\hline - Data dari perusahaan manufaktur yang tercatat di BEI selama tahun & 298 \\
2012-2013. & $(12)$ \\
- Perusahaan manufaktur yang tidak memiliki kelengkapan data untuk & \\
penelitian ini. & $(58)$ \\
- Perusahaan manufaktur yang menyajikan laporan keuangan dengan mata & \\
uang selain rupiah. & 228 \\
- Total Sampel Selama Periode Penelitian 2012-2013. & \\
\hline
\end{tabular}

\section{Statistik Deskriptif}

Statistik deskriptif merupakan pengujian statistik secara umum yang bertujuan untuk melihat distribusi data dari variabel yang digunakan dalam penelitian ini. Berikut ini statistik deskriptif dari masing-masing variabel penelitian.

Tabel 2

Statistik Deskriptif

\begin{tabular}{lccccc}
\hline \multicolumn{1}{c}{ Variabel } & Jumlah data & Minimum & Maksimum & Rata-rata & Standard Deviasi \\
\hline Konservatisme & 134 & $-0,629$ & 0,431 & $-0,040$ & 0,123 \\
Company Growth & 134 & $-0,335$ & 0,442 & 0,117 & 0,117 \\
Profitability & 134 & $-1,182$ & 1,258 & 0,113 & 0,198 \\
Investment Opportunity Set & 134 & $-0,037$ & 0,279 & 0,046 & 0,057 \\
\hline
\end{tabular}

Sumber: Data diolah, 2015 
Berdasarkan Tabel 2 nilai rata-rata tingkat konservatisme akuntansi pada perusahaan yang terdaftar di BEI pada tahun 2012 dan 2013 sebesar -0,040. Hasil ini menunjukkan bahwa sebagian besar perusahaan tingkat konservatisme akuntansinya rendah karena nilai rata-ratanya lebih kecil dari nol. Variabel company growth menunjukkan rata-rata sebesar 0,117 . Hal ini menunjukkan rata-rata perusahaan mengalami pertumbuhan penjualan sebesar 11,7 persen. Variabel profitability menunjukkan rata-rata sebesar 0,113 . Hal ini menunjukkan rata-rata perusahaan memperoleh keuntungan sebesar 11,3 persen. Variabel IOS memiliki nilai rata-rata 0,046. Hal ini menunjukkan bahwa sebagian besar perusahaan bertumbuh.

\section{Uji Normalitas}

Uji normalitas data dalam penelitian ini menggunakan uji KolmogorovSmirnov terhadap data residual regresi. Hasil pengujian normalitas ditunjukkan pada Tabel 3 (Lampiran 1) dengan Kolmogorov-Smirnov dan dengan jumlah data 228 menunjukkan bahwa nilai signifikansi atas uji KolmogorovSmirnov adalah 0,000 yang lebih kecil dari tingkat signifikansi penelitian 5 persen.

Hasil pengujian ini mengindikasikan bahwa data yang digunakan dalam penelitian ini tidak terdistribusi secara normal. Untuk memperoleh data yang terdistribusi normal, penelitian ini menggunakan metoda outlier data berdasarkan nilai Z-score data penelitian. Dalam cara normalitas data ini, nilai Z-score data yang ekstrim atas keseluruhan data dikeluarkan dan tidak dijadikan data observasi dalam penelitian.

Setelah dilakukan analisis dengan Z-score, diperoleh 134 data observasi. Hasil analisis Z-score ini mengindikasikan bahwa 94 data observasi dikeluarkan dari sampel penelitian. Dengan data observasi sejumlah 134 ini kemudian diuji normalitas data berdasarkan nilai residu dengan menggunakan uji Kolmogorov-Smirnov. Hasil uji normalitas Kolmogorov-Smirnov pada tabel 4 menunjukkan nilai signifikansinya adalah 0,096 yang lebih besar dari 0,05 atau 5 persen, dengan demikian dapat dinyatakan bahwa data terdistribusi secara normal.

Uji autokorelasi adalah untuk melihat apakah terjadi korelasi antara suatu periode dengan periode sebelumnya. Dalam penelitian ini digunakan metoda pengujian Durbin-Watson dengan hasil output nilai Durbin-Watson atau $D W$ yang di tunjukkan pada Tabel 5 yaitu sebesar 1,808. Nilai DW akan dibandingkan dengan nilai tabel signifikansi 5 persen pada tabel Durbin-Watson dengan jumlah sampel 134 dan jumlah variabel independen 3 sehingga diperoleh nilai du 1,7638.

Nilai Durbin-Watson yaitu 1,808 lebih besar dari $d u$ yaitu 1,798 dan kurang dari (4-du) 4-1,798 = 2,202 sehingga dapat di simpulkan bahwa tidak terdapat autokorelasi artinya bahwa model regresi penelitian ini bebas dari autokorelasi. Uji multikolinieritas digunakan untuk mengetahui korelasi antar variabel independen. Model regresi yang baik adalah model yang tidak terdapat korelasi antara variabel independen atau korelasi antar variabel independennya rendah. Keberadaan 
multikolinieritas dideteksi dengan Varians Inflating Factor (VIF) dan Tolerance. Uji Multikolinieritas pada Tabel 6 menunjukkan bahwa semua variabel independen memiliki nilai tolerance lebih dari 0,1 dan semua variabel independen memiliki nilai VIF lebih dari 1 dan kurang dari 10. Jadi dapat dikatakan bahwa tidak terjadi multikolinearitas antar variabel independen dalam model regresi.

Uji heteroskedastisitas perlu dilakukan untuk mengetahui apakah ada ketidaksamaan varian dari residual untuk semua pengamatan pada model regresi. Untuk mengetahui ada tidaknya gejala heteroskedastisitas dalam penelitian ini menggunakan uji glejser. Cara membaca kesimpulan pada uji glejser ini adalah dengan melihat nilai signifikansi dalam tabel coefficients yaitu pada kolom Sig. pada hasil olah data, apabila nilai Sig. lebih besar dari 0,05 maka tidak ada gejala heteroskedastistias. Hasil uji heterokedastisitas pada Tabel 7 menunjukkan model regresi yang digunakan dalam penelitian ini tidak terjadi heteroskedastisitas, dimana tingkat signifikansi untuk semua variabel independen di atas 0,05.

\section{Uji Hipotesis}

Pengujian hipotesis dalam penelitian ini menggunakan analisis regresi berganda dilakukan dengan uji $\mathrm{t}$ untuk mengetahui hubungan antara variable independen dengan variabel dependen secara simultan dan uji F untuk mengetahui hubungan antara variabel independen dengan variabel dependen secara parsial yang ditunjukkan pada Tabel 4 dan 5.

Tabel 4

Uji F dan Uji Koefisien Determinasi

\begin{tabular}{|c|c|c|c|c|}
\hline Sig. & Adjusted R Square & $\mathbf{F}$ & Kriteria Pengujian & Keterangan \\
\hline 0,000 & 0,204 & 12,344 & Sig. $<0,05$ & Signifikan \\
\hline
\end{tabular}

Koefisien determinasi menyatakan persentase total variasi dari variabel dependen yang dapat dijelaskan oleh variabel independen dalam model. Besarnya sumbangan dari variabel independen dalam menjelaskan variabel dependen secara simultan dapat dilihat dari besarnya koefisien determinasi simultan (adjusted $\mathrm{R}^{2}$ ). Untuk model regresi dengan variabel independen lebih dari dua koefisien determinasi menggunakan nilai adjusted $R$ square. Dari hasil pengujian dengan analisis regresi berganda yang telah dilakukan, pada Tabel 4 diperoleh nilai Adjusted $\mathrm{R}^{2}$ sebesar 0,204. Hal ini menunjukkan bahwa sebesar 20,4 persen variasi dari konservatisme akuntansi dapat dijelaskan oleh variabel company growth, profitability, dan IOS. Sedangkan sisanya sebesar 79,6 persen dijelaskan oleh variabel lain di luar model.

Berdasarkan Tabel 4 menunjukkan besarnya nilai $\mathrm{F}$ yaitu 12,344 dinyatakan dengan tanda positif maka arah hubungannya adalah positif. Nilai p-value menunjukkan hasil yang signifikan yaitu sebesar $0,000 \quad(\mathrm{p}<0,05)$. Hal ini menunjukkan bahwa secara simultan variabel independen memiliki pengaruh signifikan positif terhadap variabel dependen artinya variabel independen yaitu 
company growth, profitability, dan IOS secara bersama-sama berpengaruh positif terhadap konservatisme akuntansi.

\begin{tabular}{lcccc}
\multicolumn{5}{c}{ Tabel 5 } \\
Uji t \\
\multicolumn{1}{c}{ Variabel } & Koefisien regresi & $\mathbf{t}$ & $\begin{array}{c}\text { Sig. } \\
(\boldsymbol{P} \text {-Value })\end{array}$ & Hasil Pengujian \\
\hline Konstanta & $-0,116$ & & & \\
Company Growth & 0,231 & 2,818 & 0,006 & Signifikan \\
Profitability & 0,278 & 5,597 & 0,000 & Signifikan \\
Investment Opportunity Set & 0,385 & 2,214 & 0,029 & Signifikan \\
\hline Sumber: Dapolital
\end{tabular}

Sumber: Data diolah, 2015

Berdasarkan tabel 5 maka dapat ditunjukkan bahwa secara statistik variabel company growth, profitability dan IOS berpengaruh terhadap konservatisme akuntansi, karena semua tingkat signifikansi variabel-variabel tersebut berada di bawah 0,05. Hasil pengujian menunjukkan company growth yang diukur dengan petumbuhan penjualan memiliki nilai t sebesar 2,818 dengan tingkat signifikansi 0,006 sehingga $\mathrm{H}_{1}$ dalam penelitian ini diterima. Hal ini berarti bahwa company growth berpengaruh positif terhadap konservatisme akuntansi. Hasil penelitian ini mendukung hasil penelitian Ahmed dan Duellman (2007) yaitu company growth berpengaruh positif terhadap konservatisme. Temuan ini tidak sejalan dengan hasil penelitian Zulaikha (2012) dan Saputri (2013) yaitu pertumbuhan penjualan tidak berpengaruh terhadap konservatisme. Menurut Ahmed dan Duellman (2007) pertumbuhan penjualan akan mempengaruhi tingkat akrual pada perusahaan seperti persediaan, piutang dan lainnya. Pertumbuhan penjualan akan mempengaruhi konservatisme melalui ukuran akrual dan nilai pasar. Pertumbuhan penjualan yang tinggi seringkali meningkatkan ekspektasi pasar terhadap arus kas di masa depan sehingga akan mempengaruhi konsevatisme. Pertumbuhan perusahaan di masa mendatang menandakan bahwa perusahaan telah mencapai tingkat keuntungan yang tinggi. Sehingga semakin tinggi pertumbuhan penjualan mengindikasikan bahwa perusahaan tersebut semakin konservatif.

Hasil pengujian variabel profitability yang diukur dengan $R O E$ secara statistik menunjukkan nilai $\mathrm{t}$ sebesar 5,597 dengan tingkat signifikansi 0,000 sehingga dapat disimpulkan $\mathrm{H} 2$ dalam penelitian ini didukung.. Artinya, profitability berpengaruh positif terhadap konservatisme akuntansi. Hal ini mengindikasikan bahwa semakin tinggi tingkat $R O E$ maka semakin tinggi konservatisme perusahaan. Jika $R O E$ perusahaan tinggi, maka jumlah laba ditahan akan meningkat dan menyebabkan pula peningkatan konservatisme akuntansi. Perusahaan dengan tingkat $R O E$ yang tinggi mengindikasikan bahwa kompensasi keuangan yang diberikan oleh perusahaan pada pemegang saham tinggi dan hal ini membawa kecenderungan yang tinggi bagi perusahaan untuk menerapkan prinsip konservatisme akuntansi. Hasil penelitian ini konsisten dengan penelitian Wardhani (2008); Zulaikha (2012) dan 
Saputri (2013) yang menyatakan bahwa terdapat pengaruh positif antara profitability dengan konservatisme akuntansi.

Hasil pengujian IOS secara statistik menunjukkan nilai t sebesar 0,385 dengan tingkat signifikansi 0,029 sehingga $\mathrm{H} 3$ dalam penelitian ini tidak didukung. Temuan riset ini menunjukkan IOS berpengaruh positif terhadap konservatisme akuntansi. Menurut Aggrawal dan Kyaw (2006) dalam Dwitayanti dan Fahlevi (2015) menyatakan bahwa IOS merupakan angka yang menunjukkan tingkat pertumbuhan (growth opportunity) yang dimiliki perusahaan. Tingkat pertumbuhan penjualan yang tinggi seringkali meningkatkan ekspektasi pasar terhadap arus kas di masa depan sehingga akan mempengaruhi konservatisme. Hal ini mengindikasikan adanya hubungan positif antara IOS dengan konservatisme akuntansi menggunakan pengukuran akrual. Semakin tinggi nilai IOS yang menunjukkan tingkat pertumbuhan perusahaan maka semakin tinggi konservatisme akuntansi yang diterapkan oleh perusahaan. Hasil penelitian ini sejalan dengan hasil penelitian Dwitayanti dan Fahlevi (2015) serta penelitian Saputri (2013).

\section{SIMPULAN, KETERBATASAN DAN SARAN}

\section{Simpulan}

Penelitian ini bertujuan untuk menguji pengaruh company growth, profitability dan IOS terhadap konservatisme akuntansi. Penelitian dilakukan pada perusahaan manufaktur yang terdaftar di Bursa Efek Indonesia tahun 2012 sampai dengan 2013. Dari hasil uji analisis statistik regresi berganda didapatkan kesimpulan yaitu company growth yang diukur dengan pertumbuhan penjualan berpengaruh positif terhadap konservatisme akuntansi. Profitability yang diukur dengan $R O E$ berpengaruh positif terhadap konservatisme akuntansi. IOS berpengaruh positif terhadap konservatisme akuntansi. Secara keseluruhan penerapan konservatisme akuntansi yang dilakukan oleh perusahaan sampel mempengaruhi pertumbuhan penjualan perusahaan, profitabilitas serta kesempatan berinvestasi.

\section{Implikasi Penelitian}

Hasil penelitian ini menunjukkan adanya pengaruh antara company growth, profitability dan IOS terhadap konservatisme akuntansi. Hasil penelitian ini dapat berguna bagi perusahaan untuk melihat dan memantau pertumbuhan perusahaan, profitabilitas dan IOS sebagai indikator dalam menerapkan prinsip konservatisme akuntansi untuk mengatasi masalah keagenan. Pertimbangan bagi perusahaan untuk menerapkan prinsip konservatisme agar dapat mengatasi masalah keagenan. Secara teoritis penelitian ini membuktikan penerapan konservatisme akuntansi dapat menghindari ketidakpastian dan risiko yang berkaitan dalam situasi bisnis, menghindari perilaku oportunistik manajer serta mencegah adanya asimetri informasi. 


\section{Keterbatasan}

Tingkat adjusted $R$ square yang hanya mencapai 20,4 persen sehingga masih terdapat variabel-variabel lain yang mungkin berpengaruh lebih besar terhadap penerapan konservatisme dalam akuntansi yang tidak dimasukkan ke dalam variabel independen.

\section{Saran}

Saran yang dapat digunakan untuk perbaikan pada penelitian selanjutnya adalah menambah variabel-variabel independen lain seperti kepemilikan manajerial, kepemilikan institusional, kepemilikan publik, ukuran perusahaan dan leverage yang mungkin berpengaruh lebih besar terhadap konservatisme akuntansi. Penelitian selanjutnya dapat menggunakan lebih dari dua alat ukur konservatisme akuntansi, agar mendapatkan hasil yang komprehensif.

\section{DAFTAR PUSTAKA}

Ahmed, Anwer S., dan Scott Duellman. 2007. "Accounting conservatism and board of director characteristics: An empirical analysis." Journal of Accounting and Economics 43 (2): 411-37. https://doi.org/10.1016/j.jacceco.2007.01.005.

Almilia, L. S. 2004. "Pengujian size hypothesis dan debt/equity hypothesis yang mempengaruhi tingkat konservatisme laporan keuangan perusahaan." Jurnal Bisnis dan Akuntansi 7 (2): 237-64.

Ardina, Ayu Martaning Yogi, dan Indira Januarti. 2012. "Penggunaan perspektif positive accounting theory terhadap konservatisme akuntansi di Indonesia." Diponegoro Journal of Accounting 1 (1): 1-15.

Aristantia, Dwi, dan I Made Pande Dwiana Putra. 2015. "Investment opportunity set dan free cash flow pada tingkat pembayaran dividen perusahaan manufaktur." Jurnal Akuntansi Universitas Udayana 11 (1): 220-34.

Astuti, Elly. 2015. "Analisis pengaruh kepemilikan institusional, tingkat hutang, pertumbuhan perusahaan, profitabilitas dan ukuran perusahaan terhadap konservatisme akuntansi (studi empiris perusahaan-perusahaan listing di BEI 2011-2012)." Universitas Sebelas Maret Surakarta.

Dwitayanti, Y., dan R. Fahlevi. 2015. "Pengaruh kepemilikan manajerial, investment opportunity set, price to book ratio, dan political cost terhadap konservatisma akuntansi." Jurnal Akuntanika 2 (1): 31-43.

Gitman, Lawrence J. 2003. Principle of managerial finance. Ten edition. United States: Pearson Education, Inc.

Givoly, Dan, dan Carla Hayn. 2000. "The changing time-series properties of earnings, cash flows and accruals: Has financial reporting become more 
conservative?" Journal of Accounting and Economics 29 (3): 287-320. https://doi.org/10.1016/S0165-4101(00)00024-0.

Lafond, Ryan, dan Sugata Roychowdhury. 2007. "Managerial ownership and accounting conservatism." Journal of Accounting Research 46 (1): 101-35. https://doi.org/10.1111/j.1475-679X.2008.00268.x.

LaFond, Ryan, dan Ross L. Watts. 2006. "The information role of conservatism." $\begin{array}{lllll}\text { Accounting } & \text { Review } & 83 & \text { (2): }\end{array}$ https://doi.org/10.2308/accr.2008.83.2.447.

Lestari, H. 2004. "Pengaruh kebijakan utang, kebijakan dividen, risiko dan profitabilitas perusahaan terhadap set kesempatan investasi." In Simposium Nasional Akuntansi VII. Denpasar.

Martani, D., dan N. Dini. 2010. "The influence of operating cash flow and investment cash flow to the accounting conservatism measurement." Chinese Business Review 9 (6): 1-6.

Oktomegah, Calvin. 2012. "Faktor-faktor yang mempengaruhi penerapan konservatisme pada perusahaan manufaktur di bei." Jurnal Ilmiah Mahasiswa Akuntansi 1 (1): 36-42.

Saputri, Yuliani Diah. 2013. "Faktor-faktor yang mempengaruhi pilihan perusahaan terhadap konservatisme akuntansi." Accounting Analysis Journal 2 (2): 19198. https://doi.org/ISSN 2252-6765.

Sari, Cynthia, dan Desi Adhariani. 2009. "Konservatisme perusahaan di Indonesia dan faktor-faktor yang mempengaruhinya." In Simposium Nasional Akuntansi XII, 17. Palembang.

Wardhani, Ratna. 2008. "Tingkat konservatisme akuntansi di Indonesia dan hubungannya dengan karakteristik dewan sebagai salah satu mekanisme good coorporate governance.” In Simposium Nasional Akuntansi IX, 26. Pontianak.

Watts, Ross L. 2003. "Conservatism in accounting part I: explanations and implications." Journal of Accounting $17 \quad$ (3): 207-21. https://doi.org/10.2308/acch.2003.17.3.207.

Yenti, Yona Efri, dan Efrizal Syofyan. 2013. "Pengaruh konservatisme akuntansi terhadap penilaian ekuitas dengan good corporate governance sebagai variabel pemoderasi (studi empiris pada perusahaan manufaktur yang terdaftar di BEI)." Wahana Riset Akuntansi 1 (2): 201-18.

Zulaikha, D. W. 2012. "Pengaruh karakteristik dewan komisaris dan komite audit terhadap tingkat konservatisme akuntansi." Diponegoro Journal of Accounting 1 (2): 1-14. 


\section{LAMPIRAN 1}

Tabel 3

Pengujian Asumsi Klasik

\begin{tabular}{lccc}
\hline Jumlah Data & Asymp. Sig. & Kriteria Pengujian & Keterangan \\
\hline 228 & 0,000 & Asymp. Sig. $>0,05$ & Tidak signifikan \\
\hline Sumber: Data diolah, 2015 & &
\end{tabular}

\begin{tabular}{cccc}
\hline Jumlah Data & Asymp. Sig. & Kriteria Pengujian & Keterangan \\
\hline 134 & 0,096 & Asymp. Sig. $>0,05$ & Signifikan \\
\hline
\end{tabular}

Sumber: Data diolah, 2015

\begin{tabular}{lcccc}
\hline Durbin-Watson $(\boldsymbol{D W})$ & $\boldsymbol{d u}$ & $\mathbf{4 - d \boldsymbol { u }}$ & Kriteria Pengujian & Keterangan \\
\hline 1,808 & 1,7638 & 2,2362 & $d u<D W<(4-d u)$ & Tidak terdapat autokorelasi \\
\hline
\end{tabular}

Sumber: Data diolah, 2015

\begin{tabular}{llcl}
\hline \multicolumn{1}{c}{ Variabel } & & Tolerance & VIF \\
\hline Company Growth & 0,976 & & 1,025 \\
Profitability & 0,934 & 1,070 & \\
Investment Opportunity Set & 0,922 & 1,085 & \\
\hline
\end{tabular}

Sumber: Data diolah, 2015

\begin{tabular}{ll}
\hline Variabel & Signifikansi \\
\hline Company Growth & 0,718 \\
Profitability & 0,097 \\
Investment Opportunity Set & 0,375 \\
\hline
\end{tabular}

Sumber: Data diolah, 2015

Tabel 6

Hasil Perhitungan Konservatisme, Company Growth, Profitability, Investment Opportunity Set Perusahaan Tahun 2012

\begin{tabular}{|c|c|c|c|c|c|c|}
\hline No. & $\begin{array}{c}\text { Kode } \\
\text { Perusahaan } \\
\end{array}$ & Nama Perusahaan & Konservatisme & $\begin{array}{c}\text { Company } \\
\text { Growth } \\
\end{array}$ & Profitability & IOS \\
\hline 1 & DPNS & PT Duta Pertiwi Nusantara & $-0,02$ & 0,211 & 0,132 & $-0,001$ \\
\hline 2 & EKAD & PT Ekadharma International & $-0,028$ & 0,172 & 0,189 & 0,04 \\
\hline 3 & INCI & PT Intanwijaya International & $-0,004$ & 0,285 & 0,038 & 0,126 \\
\hline 4 & SRSN & PT Indo Acidatama & $-0,035$ & $-0,008$ & 0,063 & $-0,013$ \\
\hline 5 & BIMA & PT Primarindo Asia Infrastructure & 0,009 & 0,321 & $-0,014$ & $-0,002$ \\
\hline 6 & BATA & PT Sepatu Bata & $-0,044$ & 0,107 & 0,179 & 0,032 \\
\hline 7 & GJTL & PT Gajah Tunggal & $-0,037$ & 0,062 & 0,207 & 0,119 \\
\hline 8 & INTA & PT Intraco Penta & $-0,376$ & $-0,136$ & 0,0248 & 0,012 \\
\hline 9 & LPIN & PT Multi Prima Sejahtera & $-0,01$ & 0,0918 & 0,123 & 0,016 \\
\hline 10 & NIPS & PT Nipress & $-0,023$ & 0,213 & 0,1 & 0,073 \\
\hline 11 & PRAS & PT Prima Alloy Steel Universal & $-0,012$ & $-0,061$ & 0,056 & 0,054 \\
\hline 12 & SMSM & PT Selamat Sempurna & $-0,027$ & 0,197 & 0,327 & 0,075 \\
\hline 13 & JECC & PT Jembo Cable Company & $-0,052$ & $-0,026$ & 0,222 & $-0,011$ \\
\hline 14 & KBLM & PT Kabelindo Murni & $-0,117$ & 0,18 & 0,09 & 0,011 \\
\hline 15 & KBLI & PT KMI Wire and Cable & $-0,136$ & 0,234 & 0,148 & 0,002 \\
\hline 16 & $\mathrm{SCCO}$ & $\begin{array}{l}\text { PT Supreme Cable Manufacturing } \\
\& \text { Commerce }\end{array}$ & $-0,066$ & 0,053 & 0,26 & 0,015 \\
\hline 17 & VOKS & PT Voksel Electric & $-0,096$ & 0,233 & 0,244 & 0,023 \\
\hline
\end{tabular}




\begin{tabular}{|c|c|c|c|c|c|c|}
\hline No. & $\begin{array}{c}\text { Kode } \\
\text { Perusahaan } \\
\end{array}$ & Nama Perusahaan & Konservatisme & $\begin{array}{l}\text { Company } \\
\text { Growth }\end{array}$ & Profitability & IOS \\
\hline 18 & INTP & PT Indocement Tunggal Prakarsa & 0,224 & 0,245 & 0,245 & 0,013 \\
\hline 19 & BUDI & $\begin{array}{l}\text { PT Budi Acid Jaya (Starch \& } \\
\text { Sweetner) }\end{array}$ & $-0,104$ & $-0,083$ & 0,006 & 0,027 \\
\hline 20 & ETWA & PT Eterindo Wahanatama & $-0,117$ & $-0,335$ & 0,068 & 0,184 \\
\hline 21 & LTLS & PT Lautan Luas & 0,152 & 0,124 & 0,096 & 0,064 \\
\hline 22 & TCID & PT Mandom Indonesia & 0,033 & 0,119 & 0,137 & 0,019 \\
\hline 23 & MBTO & PT Martina Berto & $-0,075$ & 0,107 & 0,105 & 0,022 \\
\hline 24 & MRAT & PT Mustika Ratu & $-0,032$ & 0,128 & 0,08 & 0,011 \\
\hline 25 & MTDL & PT Metrodata Electronics & $-0,229$ & 0,173 & 0,167 & 0,054 \\
\hline 26 & MLPL & PT Multipolar & $-0,079$ & 0,224 & 0,024 & 0,023 \\
\hline 27 & $\mathrm{KICI}$ & PT Kedaung Indah can & $-0,003$ & 0,083 & 0,034 & 0,015 \\
\hline 28 & KDSI & PT Kedawung Setia Industrial & 0,001 & 0,102 & 0,117 & $-0,015$ \\
\hline 29 & FAST & PT Fast food indonesia & 0,187 & 0,073 & 0,208 & 0,039 \\
\hline 30 & MYOR & PT Mayora indah & $-0,184$ & 0,112 & 0,243 & 0,099 \\
\hline 31 & PSDN & PT Prasidha aneka niaga & $-0,039$ & 0,047 & 0,063 & 0,239 \\
\hline 32 & SKLT & PT Sekar laut & $-0,004$ & 0,166 & 0,062 & 0,005 \\
\hline 33 & STTP & PT Siantar top & $-0,096$ & 0,249 & 0,129 & 0,057 \\
\hline 34 & TBLA & PT Tunas baru lampung & $-0,397$ & 0,02 & 0,139 & 0,071 \\
\hline 35 & ULTJ & $\begin{array}{l}\text { PT Ultrajaya milk industry \& } \\
\text { trading company }\end{array}$ & 0,017 & 0,337 & 0,211 & $-0,037$ \\
\hline 36 & ALMI & PT Alumindo Light Metal Industry & $-0,092$ & $-0,108$ & 0,024 & 0,029 \\
\hline 37 & BTON & PT Betonjaya Manunggal & 0,001 & 0,009 & 0,219 & 0,034 \\
\hline 38 & INAI & PT Indal Almuminium Industry & $-0,131$ & 0,048 & 0,179 & 0,02 \\
\hline 39 & LMSH & PT Lion Mesh Prima & $-0,033$ & 0,075 & 0,423 & 0,027 \\
\hline 40 & LION & PT Lion Metal Works & $-0,023$ & 0,244 & 0,23 & 0,027 \\
\hline 41 & BAJA & PT Saranacentral Bajatama & $-0,096$ & 0,189 & 0,074 & 0,046 \\
\hline 42 & TIRA & PT Tira Austenite & $-0,035$ & $-0,062$ & 0,066 & 0,028 \\
\hline 43 & ALDO & PT Alkindo Naratama & $-0,009$ & 0,142 & 0,13 & 0,011 \\
\hline 44 & SPMA & PT Suparma & $-0,087$ & 0,072 & 0,051 & 0 \\
\hline 45 & DVLA & PT Darya-varia Laboratoria & $-0,059$ & 0,118 & 0,177 & 0,022 \\
\hline 46 & INAF & PT Indofarma & $-0,051$ & $-0,039$ & 0,065 & $-0,003$ \\
\hline 47 & KAEF & PT Kimia Farma & $-0,006$ & 0,073 & 0,14 & 0,011 \\
\hline 48 & MERK & PT Merck & 0,02 & 0,012 & 0,259 & 0,003 \\
\hline 49 & PYFA & PT Pyridam Farma & $-0,012$ & 0,17 & 0,061 & 0,081 \\
\hline 50 & SCPI & $\begin{array}{l}\text { PT Schering Plough Indonesia } \\
\text { (Merck sharp dohme pharma) }\end{array}$ & 0,025 & 0,108 & $-0,715$ & 0,279 \\
\hline 51 & SQBB & PT Taisho Phamaceutical Indonesia & $-0,008$ & 0,134 & 0,416 & 0,016 \\
\hline 52 & TSPC & PT Tempo Scan Pacific & $-0,113$ & 0,147 & 0,189 & 0,025 \\
\hline 53 & INTD & PT Inter Delta & 0 & $-0,069$ & 0,202 & 0 \\
\hline 54 & MDRN & PT Modern International & $-0,053$ & 0,125 & 0,057 & 0,063 \\
\hline 55 & KONI & PT Perdana Bangun Pustaka & $-0,001$ & 0,163 & 0,078 & $-0,009$ \\
\hline 56 & AKPI & PT Argha Karya Prima Industry & $-0,068$ & 0,002 & 0,037 & 0,018 \\
\hline 57 & AMFG & PT Asahimas Flat Glass & $-0,098$ & 0,101 & 0,141 & 0,075 \\
\hline 58 & APLI & PT Asiaplast Industries & $-0,033$ & 0,114 & 0,019 & 0,01 \\
\hline
\end{tabular}




\begin{tabular}{|c|c|c|c|c|c|c|}
\hline No. & $\begin{array}{c}\text { Kode } \\
\text { Perusahaan }\end{array}$ & Nama Perusahaan & Konservatisme & $\begin{array}{l}\text { Company } \\
\text { Growth }\end{array}$ & Profitability & IOS \\
\hline 59 & BRNA & PT Berlina & $-0,024$ & 0,232 & 0,181 & 0,117 \\
\hline 60 & IGAR & PT Champion Pacific Indonesia & $-0,052$ & 0,085 & 0,184 & 0,048 \\
\hline 61 & LMPI & $\begin{array}{l}\text { PT Langgeng Makmur Plastik } \\
\text { Industri }\end{array}$ & $-0,038$ & 0,191 & 0,006 & 0,055 \\
\hline 62 & SIAP & PT Sekawan Inti Pratama & 0,008 & 0,042 & 0,032 & 0,088 \\
\hline 63 & SIMA & PT Siwani Makmur & 0,001 & 0,27 & 0,335 & $-0,016$ \\
\hline 64 & TRST & PT Trias Sentosa & $-0,154$ & $-0,038$ & 0,045 & 0,043 \\
\hline 65 & YPAS & PT Yanaprima Hastapersada & $-0,055$ & 0,109 & 0,1 & 0,17 \\
\hline 66 & ARNA & PT Arwana Citramulia & 0,026 & 0,207 & 0,262 & 0,036 \\
\hline 67 & KIAS & PT Keramika Indonesia Assosiasi & $-0,008$ & 0,199 & 0,036 & 0,013 \\
\hline 68 & TOTO & PT Surya Toto Indonesia & $-0,109$ & 0,175 & 0,263 & $-0,01$ \\
\hline 69 & HDTX & PT Panasia Indo Resources & $-0,001$ & $-0,153$ & 0,005 & 0,134 \\
\hline 70 & RDTX & PT Roda Vivatex & 0,035 & 0,114 & 0,131 & 0,087 \\
\hline 71 & SSTM & PT Sunson Textile Manufacture & 0,043 & 0,375 & $-0,05$ & 0,009 \\
\hline 72 & WIIM & PT Wismilak Inti Makmur & $-0,091$ & 0,209 & 0,118 & $-0,001$ \\
\hline
\end{tabular}




\section{LAMPIRAN 2}

Tabel 7

Hasil Perhitungan Konservatisme, Company Growth, Profitability, Investment Opportunity Set Perusahaan Tahun 2013

\begin{tabular}{|c|c|c|c|c|c|c|}
\hline No. & $\begin{array}{c}\text { Kode } \\
\text { Perusahaan } \\
\end{array}$ & Nama Perusahaan & Konservatisme & $\begin{array}{c}\text { Company } \\
\text { Growth }\end{array}$ & Profitability & IOS \\
\hline 1 & DPNS & PT Duta Pertiwi Nusantara & $-0,071$ & $-0,105$ & 0,299 & 0,003 \\
\hline 2 & EKAD & PT Ekadharma International & $-0,037$ & 0,087 & 0,166 & 0,056 \\
\hline 3 & INCI & PT Intanwijaya International & $-0,003$ & 0,257 & 0,819 & 0,127 \\
\hline 4 & MYRX & PT Hanson International & 0,089 & 0,442 & 0 & $-0,001$ \\
\hline 5 & SRSN & PT Indo Acidatama & $-0,018$ & 0,021 & 0,05 & 0,09 \\
\hline 6 & BIMA & PT Primarindo Asia Infrastructure & 0,024 & 0,146 & 0,792 & $-0,007$ \\
\hline 7 & BATA & PT Sepatu Bata & $-0,023$ & 0,201 & 0,112 & 0,033 \\
\hline 8 & ASII & PT Astra International & $-0,026$ & 0,031 & 0,21 & 0,017 \\
\hline 9 & LPIN & PT Multi Prima Sejahtera & $-0,017$ & 0,124 & 0,06 & 0 \\
\hline 10 & NIPS & PT Nipress & $-0,126$ & 0,297 & 0,144 & 0,054 \\
\hline 11 & PRAS & PT Prima Alloy Steel Universal & $-0,102$ & 0,019 & 0,033 & 0,117 \\
\hline 12 & SMSM & PT Selamat Sempurna & $-0,168$ & 0,097 & 0,336 & $-0,013$ \\
\hline 13 & TURI & PT Tunas Ridean & $-0,159$ & 0,105 & 0,155 & 0,051 \\
\hline 14 & JECC & PT Jembo Cable Company & $-0,043$ & 0,207 & 0,153 & 0,052 \\
\hline 15 & KBLM & PT Kabelindo Murni & $-0,131$ & 0,012 & 0,029 & 0,015 \\
\hline 16 & KBLI & PT KMI Wire and Cable & $-0,125$ & 0,132 & 0,083 & 0,002 \\
\hline 17 & SCCO & $\begin{array}{l}\text { PT Supreme Cable Manufacturing \& } \\
\text { Commerce }\end{array}$ & $-0,129$ & 0,059 & 0,148 & 0,017 \\
\hline 18 & SMCB & PT Holcim Indonesia & 0,385 & 0,075 & 0,109 & 0,187 \\
\hline 19 & SMGR & PT Semen Indonesia & $-0,001$ & 0,25 & 0,246 & 0,067 \\
\hline 20 & BUDI & $\begin{array}{lrlll}\text { PT Budi Acid Jaya } & \text { (Starch } & \text { \& } \\
\text { Sweetner) } & & & & \end{array}$ & 0,057 & 0,119 & 0,049 & 0 \\
\hline 21 & LTLS & PT Lautan Luas & $-0,214$ & $-0,077$ & 0,092 & 0,008 \\
\hline 22 & TCID & PT Mandom Indonesia & 0,023 & 0,096 & 0,135 & 0,167 \\
\hline 23 & MBTO & PT Martina Berto & $-0,037$ & $-0,107$ & 0,036 & 0,088 \\
\hline 24 & UNVR & PT Unilever Indonesia & 0,431 & 0,127 & 1,258 & 0,044 \\
\hline 25 & ASGR & PT Astra Graphia & $-0,052$ & 0,096 & 0,284 & 0,013 \\
\hline 26 & KICI & PT Kedaung Indah can & $-0,006$ & 0,045 & 0,1 & $-0,007$ \\
\hline 27 & KDSI & PT Kedawung Setia Industrial & 0,036 & 0,065 & 0,1 & 0,201 \\
\hline 28 & ADES & PT Akasha wira international & $-0,036$ & 0,054 & 0,21 & 0,073 \\
\hline 29 & FAST & PT Fast food indonesia & 0,209 & 0,113 & 0,142 & 0,014 \\
\hline 30 & INDF & PT Indofood sukses makmur & 0,223 & 0,153 & 0,089 & 0,093 \\
\hline 31 & ROTI & PT Nippon indosari corporindo & 0,093 & 0,264 & 0,201 & 0,154 \\
\hline 32 & PTSP & PT Pioneerindo gourmet international & $-0,031$ & 0,104 & 0,162 & 0,072 \\
\hline 33 & SKLT & PT Sekar laut & 0,001 & 0,412 & 0,082 & 0,08 \\
\hline 34 & TBLA & PT Tunas baru lampung & $-0,411$ & $-0,026$ & 0,048 & 0,092 \\
\hline 35 & ULTJ & $\begin{array}{l}\text { PT Ultrajaya milk industry \& trading } \\
\text { company }\end{array}$ & $-0,254$ & 0,232 & 0,161 & $-0,005$ \\
\hline 36 & INAI & PT Indal Almuminium Industry & 0,062 & 0,1 & 0,04 & 0,001 \\
\hline 37 & JKSW & PT Jakarta Kyoei Steel Works & 0,007 & 0,064 & 0,02 & 0 \\
\hline
\end{tabular}




\begin{tabular}{|c|c|c|c|c|c|c|}
\hline No. & $\begin{array}{c}\text { Kode } \\
\text { Perusahaan }\end{array}$ & Nama Perusahaan & Konservatisme & $\begin{array}{c}\text { Company } \\
\text { Growth }\end{array}$ & Profitability & IOS \\
\hline 38 & LMSH & PT Lion Mesh Prima & $-0,003$ & 0,149 & 0,13 & $-0,003$ \\
\hline 39 & LION & PT Lion Metal Works & $-0,017$ & $-0,001$ & 0,156 & 0,06 \\
\hline 40 & PICO & PT Pelangi Indah Canindo & $-0,036$ & 0,154 & 0,072 & $-0,014$ \\
\hline 41 & SPMA & PT Suparma & 0,019 & 0,095 & $-0,032$ & 0,016 \\
\hline 42 & DVLA & PT Darya-varia Laboratoria & $-0,051$ & 0,013 & 0,138 & 0,021 \\
\hline 43 & INAF & PT Indofarma & 0,002 & 0,157 & $-0,092$ & 0,022 \\
\hline 44 & $\mathrm{KAEF}$ & PT Kimia Farma & 0,007 & 0,164 & 0,133 & 0,02 \\
\hline 45 & MERK & PT Merck & 0 & 0,284 & 0,342 & $-0,002$ \\
\hline 46 & PYFA & PT Pyridam Farma & $-0,02$ & 0,09 & 0,066 & 0,179 \\
\hline 47 & SQBB & PT Taisho Phamaceutical Indonesia & $-0,009$ & 0,1 & 0,431 & 0,006 \\
\hline 48 & TSPC & PT Tempo Scan Pacific & $-0,321$ & 0,034 & 0,165 & 0,038 \\
\hline 49 & INTD & PT Inter Delta & $-0,003$ & 0,034 & 0,182 & 0,03 \\
\hline 50 & KONI & PT Perdana Bangun Pustaka & $-0,01$ & 0,366 & $-0,371$ & 0,03 \\
\hline 51 & AKPI & PT Argha Karya Prima Industry & $-0,265$ & 0,102 & 0,034 & 0,09 \\
\hline 52 & AMFG & PT Asahimas Flat Glass & 0,033 & 0,126 & 0,123 & 0,026 \\
\hline 53 & BRNA & PT Berlina & $-0,12$ & 0,148 & $-0,04$ & 0,188 \\
\hline 54 & IGAR & PT Champion Pacific Indonesia & $-0,044$ & 0,156 & 0,155 & 0,019 \\
\hline 55 & LMPI & PT Langgeng Makmur Plastik Industri & $-0,037$ & 0,13 & $-0,03$ & 0,007 \\
\hline 56 & SIAP & PT Sekawan Inti Pratama & $-0,01$ & 0,134 & $-0,058$ & 0,163 \\
\hline 57 & YPAS & PT Yanaprima Hastapersada & $-0,034$ & 0,063 & 0,036 & 0,034 \\
\hline 58 & KIAS & PT Keramika Indonesia Assosiasi & 0,047 & 0,167 & 0,037 & 0,058 \\
\hline 59 & TOTO & PT Surya Toto Indonesia & 0,021 & 0,085 & 0,228 & 0,056 \\
\hline 60 & STAR & PT Star Petrochem & $-0,008$ & 0,339 & 0,001 & $-0,017$ \\
\hline 61 & TRIS & PT Trisula International & $-0,037$ & 0,199 & 0,171 & 0,05 \\
\hline 62 & RMBA & PT Bentoel International Investama & $-0,629$ & 0,246 & $-1,182$ & 0,087 \\
\hline
\end{tabular}

Tabel 8

Hasil Statistik Deskriptif

Descriptive Statistics

\begin{tabular}{lrrrrr}
\hline & N & Minimum & Maximum & Mean & Std. Deviation \\
\hline ACRUAL & 134 & $-0,629$ & 0,431 & $-0,04$ & 0,123 \\
SG & 134 & $-0,335$ & 0,442 & 0,117 & 0,117 \\
ROE & 134 & $-1,182$ & 1,258 & 0,113 & 0,198 \\
IOS & 134 & $-0,037$ & 0,279 & 0,046 & 0,057 \\
Valid N (listwise) & 134 & & & & \\
\hline
\end{tabular}


Tabel 9

Hasil Uji Normalitas

Sebelum Outlier

One-Sample Kolmogorov-Smirnov Test

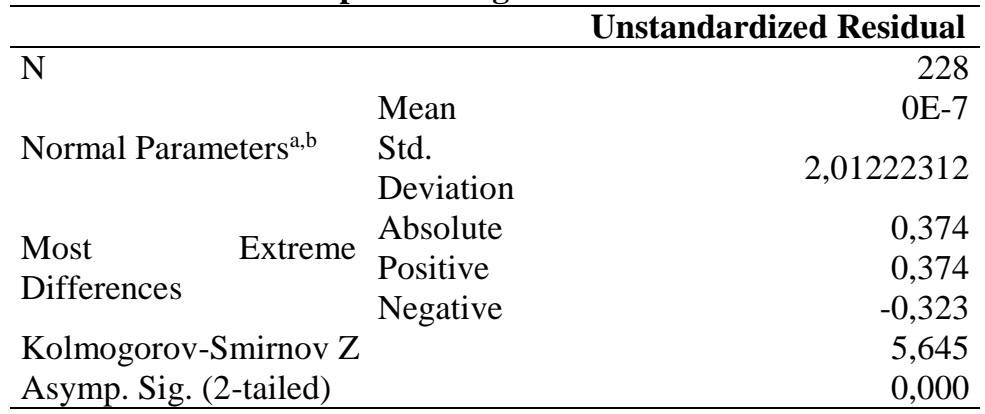

a. Test distribution is Normal.

b. Calculated from data.

Tabel 10

Setelah Outlier

One-Sample Kolmogorov-Smirnov Test

\begin{tabular}{|c|c|c|}
\hline \multirow{2}{*}{$\bar{N}$} & \multicolumn{2}{|c|}{ Unstandardized Residual } \\
\hline & & 134 \\
\hline & Mean & $0 \mathrm{E}-7$ \\
\hline Normal Parameters ${ }^{\mathrm{a}, \mathrm{b}}$ & $\begin{array}{l}\text { Std. } \\
\text { Deviation }\end{array}$ & 0,108 \\
\hline $\begin{array}{ll}\text { Most } & \text { Extreme } \\
\text { Differences } & \end{array}$ & $\begin{array}{l}\text { Absolute } \\
\text { Positive } \\
\text { Negative }\end{array}$ & $\begin{array}{r}0,106 \\
0,106 \\
-0,088\end{array}$ \\
\hline $\begin{array}{l}\text { Kolmogorov-Smirnov Z } \\
\text { Asymp. Sig. (2-tailed) }\end{array}$ & & $\begin{array}{l}1,232 \\
0,096 \\
\end{array}$ \\
\hline
\end{tabular}

a. Test distribution is Normal.

b. Calculated from data.

Tabel 11

Hasil Uji Autokorelasi

Model Summary ${ }^{b}$

\begin{tabular}{lrrrrr}
\hline Model & R & R Square & $\begin{array}{c}\text { Adjusted R } \\
\text { Square }\end{array}$ & $\begin{array}{c}\text { Std. Error of } \\
\text { the Estimate }\end{array}$ & $\begin{array}{l}\text { Durbin- } \\
\text { Watson }\end{array}$ \\
\hline 1 & $0,471^{\mathrm{a}}$ & 0,222 & 0,204 & 0,11 & 1,808 \\
\hline
\end{tabular}

a. Predictors: (Constant), IOS, SG, ROE

b. Dependent Variable: ACRUAL 
Tabel 12

Hasil Uji Multikolinearitas

Coefficients $^{\mathrm{a}}$

\begin{tabular}{|c|c|c|c|c|c|c|c|c|}
\hline & \multirow[t]{2}{*}{ Model } & \multicolumn{2}{|c|}{$\begin{array}{l}\text { Unstandardized } \\
\text { Coefficients }\end{array}$} & \multirow{2}{*}{$\begin{array}{c}\begin{array}{c}\text { Standardized } \\
\text { Coefficients }\end{array} \\
\text { Beta }\end{array}$} & \multirow[t]{2}{*}{$\mathbf{t}$} & \multirow{2}{*}{ Sig. } & \multicolumn{2}{|c|}{$\begin{array}{l}\text { Collinearity } \\
\text { Statistics }\end{array}$} \\
\hline & & B & Std. Error & & & & Tolerance & VIF \\
\hline \multirow{4}{*}{1} & (Constant) & 0,116 & 0,018 & & 6,357 & 0,000 & & \\
\hline & $\mathrm{SG}$ & $-0,231$ & 0,082 & $-0,221$ & $-2,818$ & 0,006 & 0,976 & 1,025 \\
\hline & ROE & $-0,278$ & 0,050 & $-0,448$ & $-5,597$ & 0,000 & 0,934 & 1,070 \\
\hline & IOS & $-0,385$ & 0,174 & $-0,178$ & $-2,214$ & 0,029 & 0,922 & 1,085 \\
\hline
\end{tabular}

a. Dependent Variable: ACRUAL

Tabel 13

Hasil Uji Heteroskedastisitas

Coefficients $^{\mathrm{a}}$

\begin{tabular}{|c|c|c|c|c|c|c|}
\hline & \multirow[t]{2}{*}{ Model } & \multicolumn{2}{|c|}{ Unstandardized Coefficients } & \multirow{2}{*}{$\begin{array}{c}\begin{array}{c}\text { Standardized } \\
\text { Coefficients }\end{array} \\
\text { Beta } \\
\end{array}$} & \multirow[t]{2}{*}{$\mathbf{t}$} & \multirow[t]{2}{*}{ Sig. } \\
\hline & & $\mathbf{B}$ & Std. Error & & & \\
\hline \multirow{4}{*}{1} & (Constant) & 0,081 & 0,012 & & 6,519 & 0,000 \\
\hline & SG & $-0,020$ & 0,056 & $-0,032$ & $-0,362$ & 0,718 \\
\hline & ROE & $-0,057$ & 0,034 & $-0,149$ & $-1,673$ & 0,097 \\
\hline & IOS & 0,106 & 0,119 & 0,080 & 0,890 & 0,375 \\
\hline
\end{tabular}

a. Dependent Variable: absres

Tabel 14

Hasil Uji Koefisien Determinasi

Model Summary

\begin{tabular}{lcrrr}
\hline Model & R & R Square & $\begin{array}{c}\text { Adjusted R } \\
\text { Square }\end{array}$ & $\begin{array}{c}\text { Std. Error of } \\
\text { the Estimate }\end{array}$ \\
\hline 1 & $0,471^{\text {a }}$ & 0,222 & 0,204 & 0,11 \\
\hline a. Predictors: (Constant), IOS, SG, ROE &
\end{tabular}

Tabel 15

Hasil Uji Regresi Linier: Uji F Dan Uji T

ANOVA $^{a}$

\begin{tabular}{llrrrrr}
\hline Model & & Sum of Squares & df & Mean Square & F & Sig. \\
\hline \multirow{3}{*}{1} & Regression & 0,444 & 3 & 0,148 & 12,344 & $0,000^{\mathrm{b}}$ \\
& Residual & 1,559 & 130 & 0,012 & & \\
& Total & 2,003 & 133 & & & \\
\hline
\end{tabular}

a. Dependent Variable: ACRUAL

b. Predictors: (Constant), IOS, SG, ROE

Tabel 16

Coefficients $^{\mathrm{a}}$

\begin{tabular}{rlrrrrr}
\hline \multirow{2}{*}{ Model } & \multicolumn{2}{c}{ Unstandardized Coefficients } & $\begin{array}{c}\text { Standardized } \\
\text { Coefficients }\end{array}$ & T & Sig. \\
\cline { 2 - 4 } & (Constant) & B & Std. Error & Beta & & \\
\hline \multirow{3}{*}{1} & SG & $-0,116$ & 0,018 & & $-6,357$ & 0,000 \\
& ROE & 0,231 & 0,082 & $-0,221$ & 2,818 & 0,006 \\
& IOS & 0,278 & 0,050 & $-0,448$ & 5,597 & 0,000 \\
& 0,385 & 0,174 & $-0,178$ & 2,214 & 0,029 \\
\hline
\end{tabular}


a. Dependent Variable: ACRUAL 